\title{
Wellcome Trust boosts researchers' pay
}

[LONDON] In a move widely seen as a direct challenge to the UK government to increase researchers' salaries, Britain's largest medical research charity, announced last week that it is to increase the salaries of some of its research staff to 30 per cent above the basic university pay scale.

The announcement comes shortly before the delivery of a major report on UK pay and conditions in higher education, and during a pay dispute between employers and members of the higher-education union, the Association of University Teachers (AUT). The Independent Review of Higher Education Pay and Conditions, known as the Bett report after chairman Sir Michael Bett, is expected to recommend increases of up to 20 per cent for some academic staff.

The Wellcome Trust's pay rise will cost around $\mathfrak{E} 6$ million ( $\$ 9.5$ million) at first and

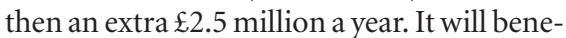
fit 270 of the trust's 3,000 or so researchers who are in its Career Development Scheme (CDS) and on contracts of three years or more. The trust says it will bring salaries of CDS researchers into line with other professions. Salaries in British universities are estimated to be 30 to 40 per cent lower than their professional counterparts outside the academic community.

"Science has become a very unattractive

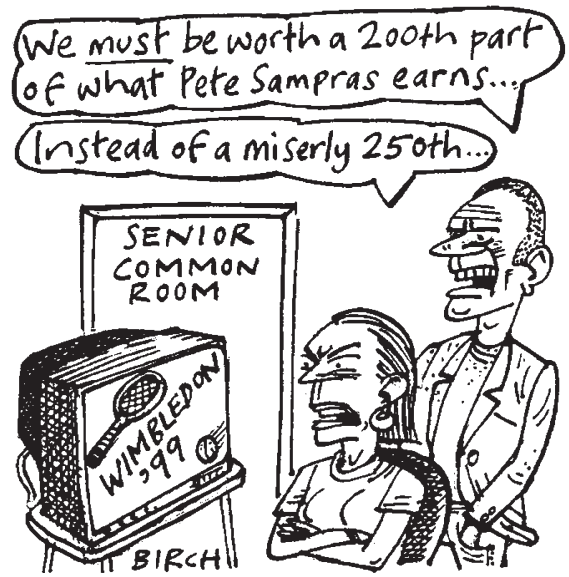

career," says Michael Dexter, the trust's director. "When we found out that some of our $\mathrm{PhD}$ students were taking a drop in pay [when getting academic appointments] we knew something was very seriously wrong."

Dexter says the trust has had recruitment problems, particularly when recruiting overseas researchers. "We are simply fetching back wages to levels 15 to 20 years ago," he says.

"Academic and research staff are not paid enough in comparison with other professional classes," says Peter Cotgreave, director of the pressure group Save British Science. "Since 1989, departments have been having trouble filling posts with good candidates."
The Bett committee was set up last year to examine pay levels, pay structures and conditions of service. Its report, due to be delivered yesterday (23 June), is expected to warn the government that a failure to find additional money will mean that institutions will struggle to maintain the quality of research and teaching. Nevertheless, even if government were to find additional money, much of it could go on equalizing pay between men and women in higher education - a gap which has been noted byleaked versions of the report.

When the report comes out this week, "we will look at expanding [the increase] to include programme and project grant applicants," says Dexter. He concedes that a wider pay increase could mean fewer, better-paid researchers. He adds that, if the best researchers are lost to other areas and overseas, then "we'll end up in a pretty poor state".

The AUT has congratulated the Wellcome Trust on the increase, and has rejected an offer of 3.5 per cent increase for academic and related staff in higher education. AUT members within pre-1992 universities are demanding a 10 per cent increase, and a second round of action is planned for August. "This is a crucial time for higher education," says David Triesman, general secretary of the AUT. "The rot of depressed pay has to stop now."

NatashaLoder

\section{Japan tightens rules on GM crops to protect the environment}

[токуо] Japan is to tighten its safety regulations on genetically modified crops following the publication last month of research suggesting that pollen from $B t$ corn could harm the larvae of monarch butterflies (see Nature 399, 214; 1999).

The Japanese Ministry of Agriculture, Forestry and Fisheries (MAFF) announced last week that it will suspend approval of $B t$ crops for agricultural purposes until its committee on genetically modified organisms (GMOs) has established criteria for evaluating the safety of such crops.

Japan has already approved the importation of six types of $B t$ corn for use as foodstuffs, but the commercial planting of seed produced by US companies, such as Monsanto, has not yet been approved.

Yutaka Tabei of the ministry's safety evaluation division says the harmful effect of $B t$ toxins on non-target insects was not entirely unexpected. "The results were not surprising, given that the butterfly larvae were fed leaves dusted with pollen from $B t$ corn," he says. "But we must carry out further studies - including those on the spread of pollen - to assess any potential impact such crops may have in the natural environment."
There is a strong emphasis on the concept of 'substantial equivalence', under which GM foods are compared with analogous conventional foods in terms of characteristics such as toxicity and nutritional qualities.At present, the GMO committee predicts the potential ecological impact of $B t$ crops to be "negligible" in the natural environment. But it is emphasizing the importance of carrying out safety tests by simulating various environmental conditions.

The committee plans to release revised safety evaluation protocols by the end of this year, basing its final decision on safety studies carried out by Japanese institutions.

The move represents the first major step by the government to review the potential ecological risks of GM crops. Until the launch of a research project in April to examine the long-term effects of herbicideand insect-tolerant crops on ecology and agricultural practices (see Nature 398, 655; 1999), the main safety concern about GM foods had focused on the risk to health.

Debates about GMOs had therefore centred on the labelling of products that contain genetically modified ingredients. Such foods are currently not labelled in Japan, and MAFF is expected to decide by the end of the year whether to require products containing GMOs to be labelled as such (see Nature 395, 628; 1998).

Japan's regulations on GMOs, which are overseen by the Ministry of Health and Welfare for food safety and by MAFF for field use, are based on guidelines set out by the Organization for Economic Cooperation and Development (OECD).

Although MAFF requires farm-scale trials of GM crops, critics say these are inadequate, as its safety evaluation protocols overlook proper assessments for long-term and 'unexpected' risks to genetic diversity.

“Although MAFF's safety evaluation of $B t$ corn requires tests on its impact on nontarget species such as mice and ladybirds, it excludes tests on butterflies by ruling out the possibility of pollen depositing on other plant species," says Setsuko Yasuda, directorgeneral of Japan's Consumers' Association.

Many see MAFF's decision to review its safety protocols as a step towards gaining public support for developments of GM technology in Japan. Japan Tobacco are planning to develop GM rice, and other companies are embarking on research into GM trees for high pulp yield and insecttolerant GM flowers.

Asako Saegusa 